\title{
Performance Scrutiny of Nepal Electricity Authority using DuPont Analysis
}

\begin{abstract}
Nischal Risal'
Abstract: The research paper aim to analyze the financial strength and weaknesses of NEA by using DuPont analysis. The descriptive and analytical research designs have been adopted in the research. The quantitative data has been obtained from annual reports of NEA. The study covers eight years period from 2011/12 to 2018/19. The study concludes despite being the sole distributor of the electricity in the country, the financial performance, measured in terms of ROE, of NEA is very poor in first five years (2010/11 - 2015/16) of the study period. The primary source of such poor performance was negative profit margin. Besides, NEA is also exposed to higher financial risk measured in terms of equity multiplier. However, both these measures, ROE and EM have improved in later two years (2016/17 - 2017/18) of the study period.
\end{abstract}

Key words : DuPont Analysis, Nepal Electricity Authority, Return on Equity

\section{INTRODUCTION}

Nepal Electricity Authority (NEA) is a government entity working as the generator, transmitter, and distributer of electricity in Nepal. NEA was formed on August 16, 1985 under the Nepal Electricity Authority Act, 1984, through the merger of the Department of Electricity of Ministry of Water Resources, Nepal Electricity Corporation and Electricity Development Boards. Merger of these organizations was felt necessary to avoid duplication of works and provide efficient service to the consumers. The primary objective of NEA is to generate, transmit and distribute adequate, reliable and affordable power by planning, constructing, operating and maintaining all generation, transmission and distribution facilities in Nepal's power system both interconnected and isolated. Nepal has immense potential of hydropower only to replace domestic energy requirement fulfilled by firewood, liquid oil and gas, agro-products etc., but also to export power to her neighbors.

1. Mr. Risal is Lecturer in Nepal Commerce Campus, Faculty of Management, Tribhuvan University. He can be reached at nischalrisal@gmail.com. 
Hydropower projects are no doubt capital intensive projects requiring huge initial investment. It is almost impossible for the government to finance all hydropower projects from its internal resources. Therefore, the government has allowed private as well as foreign investment in this sector. As a result, private sector has invested in many power projects dedicated to power generation. But still the transmission and distribution functions solely lie with NEA. To carry on these functions along with generation, it is very essential for NEA to remain financially sound. In this context, this study aims to analyze the financial strength and weaknesses of NEA by using various financial ratios including Du Pont equation.

\section{LITERATURE REVIEW}

DuPont analysis is considered as one of the most important tools for financial analysis. Most of the multinational and large companies usually make use of DuPont analysis for analyzing the performance of their businesses. Modified twice after its initial conception, the original DuPont method of financial ratio analysis was developed in 1918 by F. Donaldson Brown, an engineer at DuPont in charge of understanding the finances of a company that DuPont was acquiring, who recognized a mathematical relationship between profitability and return on equity (ROE) that was determined by return on assets (ROA). It had been reported to be the most important financial ratio as it had provided investors with the more comprehensive measured of performance (Demmer, 2015).

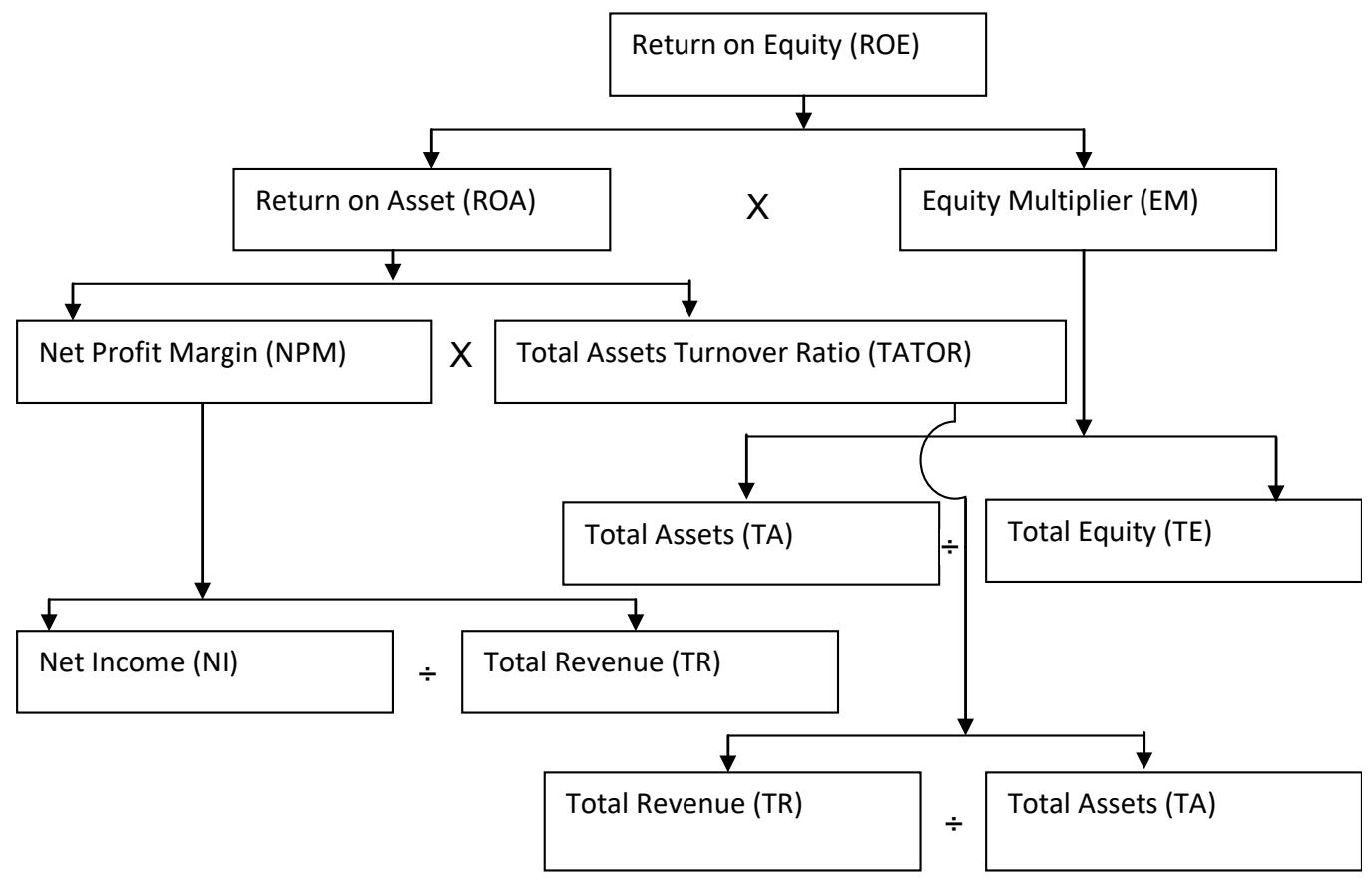

Figure 1. DuPont Chart 
DuPont analysis specially focuses on return on common equity. The DuPont Chart mentioned below shows the relationships between return on investment, asset turnover, and the profit margin. The left-hand side of the chart presents the return on assets (ROA) which is the product of profit margin and total assets turnover ratio (sales/total asset). Profit margin is calculated by dividing the net profit by sales. The various expense items are listed and then summed to obtain the total costs. Subtracting total costs from sales yields the company's net income. If the profit margin down, it could be because of either decrease in sales or increase in expense items. One can examine the individual expense items to identify which reduced the profit margin and then take corrective actions.

Equity multiplier in the right-hand side of the DuPont Chart represents the extent of the use of equity capital to finance total assets. This component not only shows the size of the business (total assets) but also incorporates the information on the way the total assets are financed. Thus, ROE depends on the capital structure of the company as measured by equity multiplier (the ratio of assets to common equity) and the rate of return on assets (profit margin multiplied by total assets turnover). The relationship is exhibited in Figure 1.

The relationship between variables can also be expressed in equation form in the following form:

Return on Equity $(\mathrm{ROE})=\mathrm{ROA} \times$ Equity Multiplier

Return on Assets $(\mathrm{ROA})=$ Net Profit Margin $\mathrm{x}$ Total Assets Turnover Ratio

Equity Multiplier $(E M)=$ Total Assets/Total Equity

Where,

Net Profit Margin $($ NPM $)=$ NPAT $/$ Sales

Total Assets Turnover Ratio (TATOR) $=$ Sales $/$ Total Assets

Evans and Bishop (2002) noted that DuPont analysis has been a popular tool to analyze the profitability of a business. By focusing on the building blocks of profitability, profit margin and asset turnover, the analysis could be extended to compute return on assets (ROA) and return on equity (ROE). The profit margin and asset turnover ratios could be used effectively in analyzing a company's historical performance and evaluating its future potential.

Soliman (2008) stated that DuPont analysis decomposes the return on net operating assets into two multiplicative components: profit margin and asset turnover. These two accounting ratios measure different constructs and have different properties. The researcher concluded the analysis of DuPont components inform about the operating characteristics of a firm and are useful for analysts' forecast revisions.

Herciu, Ogrean and Belascu (2011) studied three indicators to measure the profitability; return on sales (ROS), return on assets (ROA) and return on equity (ROE) of the top 20 most profitable companies in the world and concluded that absolute measurements are not relevant. Therefore, to have a common basis of comparison between several companies and to compose ranks, the relative sizes for measuring 
efficiency are necessary when calculating the ratio between effect and effort. The effect is the profit while efforts are either sales, total assets or the stockholders' equity. Botika (2012) suggested the fact that DuPont components represented important components for stock's abnormal returns analysis. Sheela and Karthikeyan (2012) measured the financial performance of the pharmaceutical companies using DuPont analysis. The study concluded that return on investment and return on equity are the important tool for judging the operating financial performance.

Chang, Chichernea and Hassabelnaby (2014) analyzed the informativeness of DuPont components for market participants by studying the U.S. for profit health care providers. They found that profit margin was more important than asset turnover. Marginean and Burja (2014) noted the importance of DuPont model in the study of economic and financial performance of furniture industry. The analysis of DuPont analysis has been realized through the decomposition rate of return $\mathrm{ROE}$ to other rates of return such as return on scale (ROS), return on assets (ROA) and equity multiplier (EM). Doorasamy (2016) assessed the financial performance of the top three JSE listed companies in the food industry using DuPont analysis and concluded that DuPont analysis is an important tool to measure the operating performance of a firm. Kim (2016) measured the financial performance of the food distribution company with the use of ROE, ROA applying DuPont analysis. The study concluded that return on equity and return on investment are the most comprehensive measure of profitability of a firm. Hao and Choi (2019) measured the operating performance of Chinese online shopping companies using DuPont analysis. DuPont analysis has been decomposed into return on assets, assets turnover and profit margin. The study concluded that higher assets turnover represented the efficient use of assets while the higher profit margin indicated the efficient cost structure.

\section{RESEARCH METHODS}

The research has adopted descriptive and analytical research design. The study uses only quantitative data obtained from annual reports of NEA. The research covers a period of eight fiscal years (2010/11 to 2017/18). Microsoft Excel Software has been used for tabulation, coding and encoding the data. The overall strengths and weaknesses of NEA have been analyzed through DuPont model developed by DuPont Corporation of the USA.

\section{RESULTS AND DISCUSSION}

This section presents the results of the analysis of the financial strength and weakness of NEA based on DuPont analysis.

Table 1 presents the data on return on equity (ROE) and its key components for the period $2010 / 11-2017 / 18$. The ROE is negative for the first five and has turned positive for the last two years of the study period. It was as high as $-42.77 \%$ in $2011 / 12$ which declined to $-13.17 \%$ in $2012 / 13$ and again increased till it turned positive $(2.68 \%)$ in $2016 / 17$. The primary contributor for the negative ROE is the negative net profit margin (NPM). It was $-45.67 \%$ in $2011 / 12$ which declined to $-12.51 \%$ in $2012 / 13$ and 
again increased to $-25.35 \%$ in $2015 / 16$. Then it turned positive in the following years. The impact of negative NPM is also evident in return on assets (ROA); it has followed the same pattern as the NPM. Thus, NPM, ROA and ROE have followed the same pattern, and the impact of negative NPM has passed on to ROE through ROA.

Table 1

DuPont Analysis

\begin{tabular}{llllllllll}
\hline $\begin{array}{l}\text { Ratios / } \\
\text { Fiscal Years }\end{array}$ & $2010 / 11$ & $2011 / 12$ & $2012 / 13$ & $2013 / 14$ & $2014 / 15$ & $2015 / 16$ & $2016 / 17$ & $2017 / 18$ & Average \\
\hline ROE (\%) & -22.25 & -42.77 & -13.17 & -26.00 & -20.08 & -34.18 & 2.68 & 3.67 & -19.01 \\
ROA (\%) & -4.80 & -7.26 & -2.28 & -4.12 & -2.71 & -4.22 & 0.61 & 1.02 & -2.97 \\
EM (times) & 4.63 & 5.89 & 5.78 & 6.31 & 7.42 & 8.10 & 4.37 & 3.61 & 5.76 \\
NPM (\%) & -31.50 & -45.67 & -12.51 & -22.42 & -15.41 & -25.35 & 2.91 & 4.67 & -18.16 \\
TATOR (times) & 0.15 & 0.16 & 0.18 & 0.18 & 0.18 & 0.17 & 0.21 & 0.22 & 0.18 \\
\hline
\end{tabular}

In general, TATOR measures how efficiently a company utilizes its assets to increase the total revenue. But in the context of DuPont framework it works as magnifier to the ROA. Accordingly, if net profit margin ratio is positive, higher TATOR increases ROA, but if net profit margin is negative higher TATOR pushes negative ROA further. The TATOR has increased from 0.17 in $2015 / 16$ to 0.21 in $2016 / 17$ and to 0.22 in $2017 / 18$. The TATOR magnifies the ROA which ultimately contribute to ROE. These analyses indicate that NEA has badly performed in generating profit margin per unit of revenue particularly for the first five years of the study period.

Equity multiplier (EM) denotes the portion of assets financed by equity and it is a measure of leverage. In the Dupont framework, it magnifies the ROE. Accordingly, higher EM will increase ROE, but being a measure of leverage, higher EM also indicate higher risk. The EM of NEA was 4.63 in 2010 which increased to 8.10 in 2010/11 and then declined significantly to 3.61 in $2016 / 17$. It means only about $12 \%$ of total assets were financed by equity in $2010 / 11$, but $28 \%$ of total assets was financed by equity in 2016/17. The significant decline in EM (or increased share of equity financing) in 2016/17 is attributed to sharp increase in equity in that year (Appendix 1). The analysis of EM demonstrates that NEA not only incurred heavy loss in earlier period of study but also carried on significant financial risk. However, the financial risk has significantly declined in last two years of the study.

\section{CONCLUSIONS}

The results and discussion in the previous section leads to conclude that, despite being the sole distributor of the electricity in the country, the financial performance, measured in terms of ROE, of NEA was very poor in first five years of the study period. The primary source of such poor performance was negative profit margin. Besides, NEA was also exposed to higher financial risk measured in terms of equity multiplier. However, both these measures, ROE and EM have improved in later two years of the study period. 


\section{REFERENCES}

Botika, M.(2012). The use of DuPont Analysis in abnormal returns evaluation: Empirical study of Romanian market. Procedia-Social and Behavioral Sciences, 62, 1179-1183.

Blessing, A., \& Onoja, E. E.(2015). The role of financial statements on investments decision making: A case of United Bank of Africa PLC (2004-2013). European Journal of Business, Economics and Accountancy, 3(2).

Chang, K. J., Chicherna, D.C., \& Hassabelnaby, H. R.(2014). On the DuPont Analysis in the health industry. Journal of Accounting and Public Policy, 33(1), 83-103. Retrieved from: https://doi. org/10.1016/j.jaccpubpol.2013.10.002

Hao, Y., \& Choi, S. U.(2019). Operating performance of Chinese online shopping companies: An analysis using DuPont components. Stainability Journal, 11, 3602. doi: http://dx.doi. org/10.3390/su11133602

Demmer, M. (2015). Improving profitability forecasts with information on earning quality. School of Business and Economics. Retrieved from: http://www.diss.fuberlin.de/docs/servlets/ MCRFileNodeServlet/FUDOCS_derivate_000000004923/discpaper2015_16

Doorasamy, M.(2016). Using DuPont Analysis to assess the financial performance of the top $3 \mathrm{JSE}$ listed companies in the food industry. Investment Management and Financial Innovations, 13(2), 29-44. doi:10.21511/imfi.13(2).2016.04

Evans, F. C., \& Bishop, D. M.(2002). Use and misuse of DuPont analysis in business valuation. Business Valuation Review, 21(1), 4-9. doi: https:// doi.org/10.5791/0882-2875-21.1.4

Herciu, M., Ogrean, C., \& Belascu, L.(2011). A DuPont analysis of 20 most profitable companies in the world. International Conferences on Business and Economic Research, 1, 45-48.

Horne, V. J. C., \& Wachowitz, J. M.(2004). Fundamentals of Financial Management. New York: Prentice Hall Publishers.

Kim, H. (2016). A study on financial performance using DuPont analysis in food distribution market. Culinary Science and Hospitality Research, 22(6), 52-60.

Marginean, R., \& Burja, V.(2014). The study factors that may influence the performance by the DuPont analysis in the furniture industry. Procedia Economics and Finance, 16, 213-223.

Ross, S. A., Westerfield, R. W. \& Jordan, D. B.(2007). Fundamentals of Corporate Finance. Boston: McGraw-Hill.

Sekeran, U.(2003). Research Methods for Business. New Jersey: John Wiley \& Sons.

Sharma, D. R., Thapa, K., Risal, N., Pathak, D. D.(2018). Financial Management. Kathmandu: Khanal Publication.

Sheela, C.S., \& Karthikeyan, K.(2012). Financial performance of pharmaceutical industry in India using DuPont analysis. European Journal of Business and Management, 4(14).

Soliman, M. T.(2008). The use of DuPont analysis by market participants. The Accounting Review, 83(3), 823-853. 
Annex I

(A) Selected Financial Data of Nepal Electricity Authority (In Million Rupees)

\begin{tabular}{lllllllll}
\hline Variables/Fiscal Years & $2010 / 11$ & $2011 / 12$ & $2012 / 13$ & $2013 / 14$ & $2014 / 15$ & $2015 / 16$ & $2016 / 17$ & $2017 / 18$ \\
\hline Net Income (NI) & -6089.22 & -9947.88 & -3405.41 & -6808.36 & -5129.76 & -8890.19 & 1502.28 & 2897.08 \\
Total Revenue (TR) & 19329.76 & 21784.06 & 27222.99 & 30362.6 & 33285.03 & 35073.54 & 51703.11 & 61973.74 \\
Total Current Assets (TCA) & 14367.52 & 16647.13 & 18988.6 & 21641.33 & 27501.82 & 33729.14 & 48503.49 & 64038.96 \\
Total Assets (TA) & 126780.1 & 137062.5 & 149512.8 & 165162.2 & 189544.2 & 210689.4 & 244962.4 & 284572.1 \\
Total Equity (TE) & 27372.36 & 23261.5 & 25848.15 & 26180.69 & 25545.52 & 26008.62 & 56076.41 & 78839.7 \\
Total Current Liabilities (TCL) & 36082.68 & 44198.56 & 47936.56 & 55596.67 & 65052.36 & 72683.9 & 77511.09 & 84778 \\
Total Liabilities (TL) & 99407.73 & 113801 & 123664.7 & 138981.6 & 163998.6 & 184680.8 & 188886 & 205732.4 \\
Total Equity and Total & 126780.1 & 137062.5 & 149512.8 & 165162.2 & 189544.2 & 210689.4 & 244962.4 & 284572.1 \\
Liabilities (TE \& TL) & & & & & & & &
\end{tabular}

Annex II

(B) Calculation of Selected Ratios of Nepal Electricity Authority Data Analysis

\begin{tabular}{|c|c|c|c|c|c|c|c|c|}
\hline Ratios/ Fiscal Years & $2010 / 11$ & $2011 / 12$ & $2012 / 13$ & $2013 / 14$ & $2014 / 15$ & $2015 / 16$ & $2016 / 17$ & $2017 / 18$ \\
\hline eturn on Equity (NI/TE), (\%) & 459 & -42.7654 & -13.1747 & -26.0053 & -20.0809 & -34.1817 & 987 & 3.674646 \\
\hline eturn on Assets (NI/TA), (\%) & 298 & 92 & 67 & 23 & 37 & 57 & 27 & 048 \\
\hline Equity Multiplier (TA/TE), (times) & 4.631683 & 5.892245 & 5.784275 & 552 & 7.4 & 8.100752 & 4 & 9502 \\
\hline Net Profit Margin (NI/TR), (\%) & -31.5018 & -45.6659 & -12.5093 & -22.4235 & -15.4116 & -25.3473 & 2.905589 & 4.67469 \\
\hline $\begin{array}{l}\text { Total Assets Turnover Ratio (TR/ } \\
\text { TA), (times) }\end{array}$ & $10<401$ & 0.158935 & 82078 & 1035 & 106 & 6647 & 11000 & 0.217119 \\
\hline
\end{tabular}

